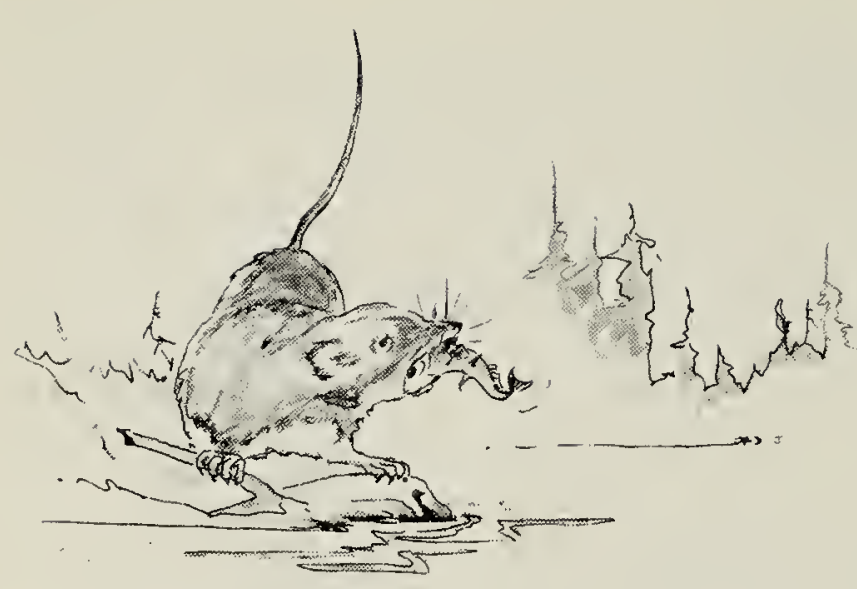

home range for this species so far as we are aware. Home ranges of the other long-tailed shrews in these areas are considerably more extensive, almost double in most cases, and the range of the Short-tailed Shrew in this habitat is some 30 per cent greater (Buckner, op. cit.).

Because the usual diet of the Water Shrew consists largely of small fishes and aquatic insects, and because in these restricted ranges fishes were unavailable and the supply of aquatic insects severely restricted, it was important to determine the feeding habits of the species under these con- ditions. The stomach contents of the seven specimens taken in snap-back traps were examined, and it was found that the largest single food class in every case was ground beetles (Carabidae). These insects formed about 30 per cent of the diet of the Water Shrew under these circumstances, and one individual had fed exclusively upon them. Next in importance was hymenopterous larvae and pupae, and third, lepidopterous pupae. Of minor importance were snails, Diptera, Arachnida, Odonata and Plecoptera. Thus is appears that the Water Shrew can behave as an opportunistic predator when the circumstances so demand.

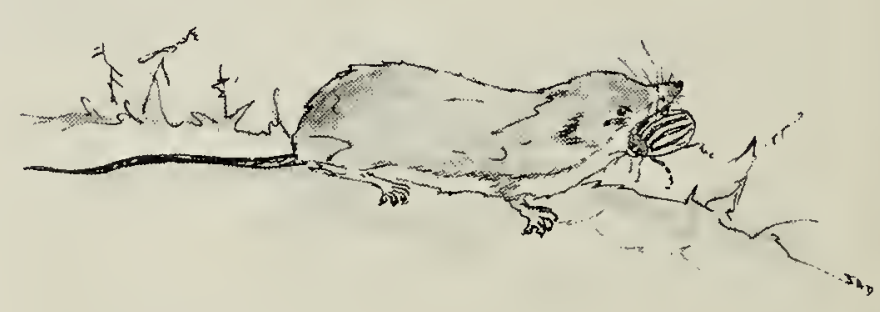

Water Shrew

Sketches by James A. Drouin

\title{
SHORT-TAILED SHREW IN NEST-BOX AT WEST SHOAL LAKE, MANITOBA
}

\author{
by Herbert W. R. Copland, Manitoba Museum of Man and Nature, \\ Winnipeg
}

A line of nest-boxes (20 at present) has been maintained for a few years at West Shoal Lake, north of Woodlands, Manitoba, by a small group of members of the Natural History Society of Manitoba, Winnipeg. The nest-boxes are positioned on trees close to the edge of long, narrow and intermittent bluffs of deciduous trees and shrubs along a low sandy ridge which is a former lake beach. The ridge is roughly parallel to and about 200 yards from the southwestern side of the lake. Primarily we were inter- ested in encouraging Eastern Bluebirds to nest, as they had been recorded in adjacent areas on a few occasions. No bluebirds have occupied any of the boxes to date but Tree Swallows and House Wrens have been using them.

On April 26, 1964, while cleaning out the boxes prior to the approaching nesting season, a mummified shrew was discovered in box No. 11. This box is mounted on a white poplar, the height of the entrance hole above ground level being seven feet. 
My notes of the previous summer show that box No: 11 on July 1 contained a Tree Swallow's nest with five young. No remains of birds were found in the box on April 26, 1964.

The shrew was submitted to Dr. C. H. Buckner, Canada Forest Research Laboratory, Winnipeg, who identified it as a Short-tailed Shrew (Blarina brevicaudo) (1964. Parasite collections. Nat. Hist. Soc. Man. Newsletter No. 4, p. 41). Recently Dr. Buckner stated that when he examined the shrew, he found the skull had been damaged by being punctured or crushed.

It is not unusual to find small mammals occupying nest-boxes. Checking their bluebird nest-boxes in 1966, the Brandon Junior Bird Club found 12 being used by White-footed Mice and a litter of three Gray Squirrels in another (Annual Report of Brandon Junior Bird Club Nest Project, 1966, Blue Jay, 24:197). Both of these species are excellent climbers.

Shrews are generally regarded as terrestrial animals, but a recent observation shows that they have considerable climbing ability. Otto Horvath (1965. Arboreal predation on bird's nest by Masked Shrew. Journ. Mamm., 46:495) notes that on May 28, 1963 near Hope, British Columbia, at the nest of a Solitary Vireo which was about five and one-half feet above the ground, a small mammal jumped from the slanting trunk of the nest-bearing tree and disappeared in the lower vegetation. When the nest-holding branch was touched two other small mammals jumped from the nest. They were collected and identified as juveniles of Sorex cinereus, the Masked or Common Shrew. "The suspended nest was mutilated and its contents thrown out; the broken shells of the three eggs lay on the ground. Although the shrews were not seen in the act of plundering, it is almost certain that they were responsible for destroying the contents of the nest."

Shrews also apparently make use of man-made structures more fre- quently than is generally believed. Two incidents strengthen this opinion. In 1965, S. E. Bland, Regina, in an article entitled "Shrew in a Beehive", (Blue Jay, 23:175) mentions finding the skeletonized remains of a shrew in a wintered hive. In addition, during inspection of bee equipment on October 22, 1965, in the Birch Hills area (Saskatchewan), he found a live shrew in a beehive set on the grass. There was evidence that the shrew had been removing dead bees from open cells of the comb in a section of the hive which had been gassed earlier for insect pests. The shrew, which died within a day or two, was later identified as a Masked Shrew.

The second case was reported by Wayne Miller of the Brandon Junior Bird Club, Brandon, in a letter to W. Harvey Beck of the Manitoba Museum of Man and Nature, Winnipeg. On June 14, 1967 he found a shrew using a nest-box positioned four feet from the ground on a farmer's fence next to a cultivated field two miles east of Douglas, Manitoba. The nest-box had a two-inch diameter entrance hole. Nest material, presumably being used by the shrew, was a gray down, much like kapok, with husks of some type of grass also present. The nest had the appearance of having been used for some time. The shrew looked dark gray in colour, had the characteristic pointed nose and the size was judged to be twice that of the Pygmy Shrew. Miller states: "It was also capable of remarkably speedy locomotion ... one reason why I don't have the specimen."

How did the Short-tailed Shrew get into the nest-box at West Shoal Lake? The evidence of the skull being damaged by puncturing or crushing suggests that a shrike or some other predatory bird had captured the shrew and stored it in the nest-box. On the other hand, judging by the above reports, the shrew could have entered the box on its own and could have been killed by the resident swallows. 